\title{
Geology and Assessment of Undiscovered Oil and Gas Resources of the Yukon Flats Basin Province, 2008
}

Chapter F of

The 2008 Circum-Arctic Resource Appraisal

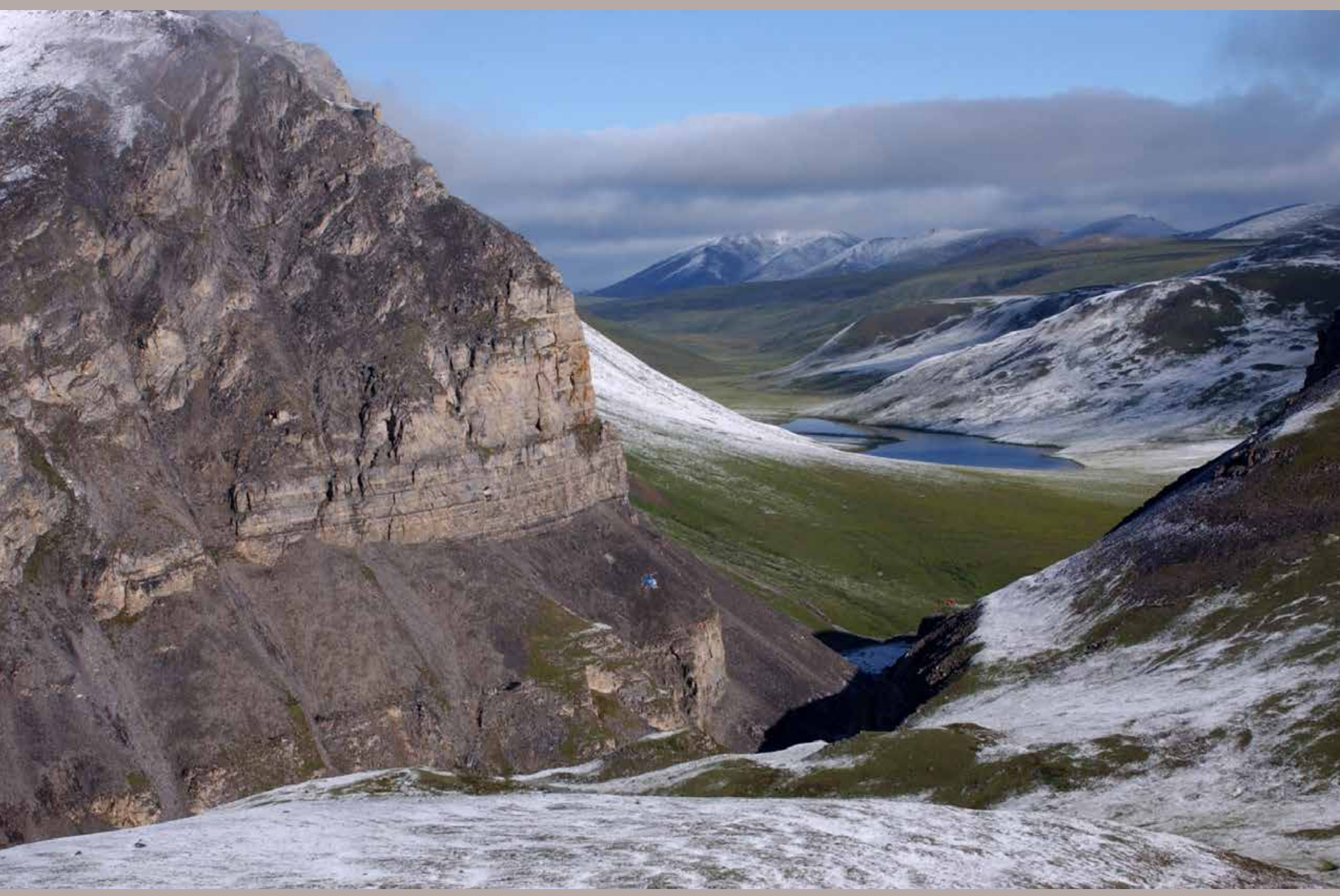

Professional Paper 1824

U.S. Department of the Interior

U.S. Geological Survey 
Cover. Northwestward view across the southern foothills of the Brooks Range along Akmagolik Creek, approximately 150 miles southwest of Prudhoe Bay, Alaska. Exposed rocks are part of the Mississippian-Pennsylvanian Lisburne Group and include a thrust-fault ramp at left. Photo includes two helicopters for scale, a blue-and-white one near the center and a red one at center-right at creek level. U.S. Geological Survey photograph by David Houseknecht. 


\section{Geology and Assessment of Undiscovered Oil and Gas Resources of the Yukon Flats Basin Province, 2008}

By Kenneth J. Bird and Richard G. Stanley

Chapter F of

The 2008 Circum-Arctic Resource Appraisal

Edited by T.E. Moore and D.L. Gautier

Professional Paper 1824 


\title{
U.S. Department of the Interior RYAN K. ZINKE, Secretary
}

\section{U.S. Geological Survey William H. Werkheiser, Acting Director}

\author{
U.S. Geological Survey, Reston, Virginia: 2017
}

For more information on the USGS — the Federal source for science about the Earth, its natural and living resources, natural hazards, and the environment-visit https://www.usgs.gov or call 1-888-ASK-USGS.

For an overview of USGS information products, including maps, imagery, and publications, visit https://store.usgs.gov.

Any use of trade, firm, or product names is for descriptive purposes only and does not imply endorsement by the U.S. Government.

Although this information product, for the most part, is in the public domain, it also may contain copyrighted materials as noted in the text. Permission to reproduce copyrighted items must be secured from the copyright owner.

Suggested citation:

Bird, K.J., and Stanley, R.G., 2017, Geology and assessment of undiscovered oil and gas resources of the Yukon Flats Basin Province, 2008, chap. F of Moore, T.E., and Gautier, D.L., eds., The 2008 Circum-Arctic Resource Appraisal: U.S. Geological Survey Professional Paper 1824, 5 p., https://doi.org/10.3133/pp1824F.

ISSN 2330-7102 (online) 


\section{The 2008 Circum-Arctic Resource Appraisal}

\section{Chapters}

A. Introduction to the 2008 Circum-Arctic Resource Appraisal (CARA) Professional Paper By Donald L. Gautier and Thomas E. Moore

B. Methodology for Assessment of Undiscovered Oil and Gas Resources for the 2008 Circum-Arctic Resource Appraisal

By Ronald R. Charpentier

\section{North America}

C. Geology and Assessment of Undiscovered Oil and Gas Resources of the Chukchi Borderland Province, 2008

By Kenneth J. Bird and David W. Houseknecht

D. Geology and Assessment of Undiscovered Oil and Gas Resources of the Hope Basin

Province, 2008

By Kenneth J. Bird, David W. Houseknecht, and Janet K. Pitman

E. Geology and Assessment of Undiscovered Oil and Gas Resources of the Arctic Alaska Petroleum Province, 2008

By David W. Houseknecht, Kenneth J. Bird, and Christopher P. Garrity

F. Geology and Assessment of Undiscovered Oil and Gas Resources of the Yukon Flats Basin Province, 2008

By Kenneth J. Bird and Richard G. Stanley

G. Geology and Assessment of Undiscovered Oil and Gas Resources of the Northwest Canada Interior Basins Province, Arctic Canada, 2008

By Marilyn E. Tennyson and Janet K. Pitman

H. Geology and Assessment of Undiscovered Oil and Gas Resources of the Franklinian Shelf Province, Arctic Canada and North Greenland, 2008

By Marilyn E. Tennyson and Janet K. Pitman

I. Geology and Assessment of Undiscovered Oil and Gas Resources of the Sverdrup Basin Province, Arctic Canada, 2008

By Marilyn E. Tennyson and Janet K. Pitman

\section{Greenland}

J. Geology and Assessment of Undiscovered Oil and Gas Resources of the West GreenlandEast Canada Province, 2008

By Christopher J. Schenk 
K. Geology and Assessment of Undiscovered Oil and Gas Resources of the East Greenland Rift Basins Province, 2008

By Donald L. Gautier

\section{North Atlantic Ocean}

L. Geology and Assessment of Undiscovered Oil and Gas Resources of the Jan Mayen Microcontinent Province, 2008

By Thomas E. Moore and Janet K. Pitman

\section{Eurasia}

M. Geology and Assessment of Undiscovered Oil and Gas Resources of the Mezen' Basin Province, 2008

By Timothy R. Klett and Janet K. Pitman

N. Geology and Assessment of Undiscovered Oil and Gas Resources of the Timan-Pechora Basin Province, Russia, 2008

By Christopher J. Schenk

0. Geology and Assessment of Undiscovered Oil and Gas Resources of the East Barents Basins Province and the Novaya Zemlya Basins and Admiralty Arch Province

By Timothy R. Klett

P. Geology and Assessment of Undiscovered Oil and Gas Resources of the North Kara Basins and Platforms Province, 2008

By Timothy R. Klett and Janet K. Pitman

0. Geology and Assessment of Undiscovered Oil and Gas Resources of the Northern West Siberian Mesozoic Composite Total Petroleum System of the West Siberian Basin Province, Russia, 2008

By Christopher J. Schenk

R. Geology and Assessment of Undiscovered Oil and Gas Resources of the Yenisey-Khatanga Basin Province, 2008

By Timothy R. Klett and Janet K. Pitman

S. Geology and Assessment of Undiscovered Oil and Gas Resources of the Northwest Laptev Sea Shelf Province, 2008

By Timothy R. Klett and Janet K. Pitman

T. Geology and Assessment of Undiscovered Oil and Gas Resources of the Lena-Anabar Basin Province, 2008

By Timothy R. Klett and Janet K. Pitman 
U. Geology and Assessment of Undiscovered Oil and Gas Resources of the Tunguska Basin Province, 2008

By Christopher J. Wandrey and Timothy R. Klett

V. Geology and Assessment of Undiscovered Oil and Gas Resources of the Lena-Vilyui Basin Province, 2008

By Timothy R. Klett and Janet K. Pitman

W. Geology and Assessment of Undiscovered Oil and Gas Resources of the Laptev Sea Shelf Province, 2008

By Timothy R. Klett and Janet K. Pitman

X. Geology and Assessment of Undiscovered Oil and Gas Resources of the Zyryanka Basin Province, 2008

By Timothy R. Klett and Janet K. Pitman

Y. Geology and Assessment of Undiscovered Oil and Gas Resources of the East Siberian Sea Basin Province, 2008

By Kenneth J. Bird, David W. Houseknecht, and Janet K. Pitman

Z. Geology and Assessment of Undiscovered Oil and Gas Resources of the Vilkitskii Basin Province, 2008

By Kenneth J. Bird, David W. Houseknecht, and Janet K. Pitman

AA. Geology and Assessment of Undiscovered Oil and Gas Resources of the Long Strait Province, Russian High Arctic, 2008

By Kenneth J. Bird, David W. Houseknecht, and Janet K. Pitman

\section{Arctic Ocean}

BB. Geology and Assessment of Undiscovered Oil and Gas Resources of the Amerasia Basin Petroleum Province, 2008

By David W. Houseknecht, Kenneth J. Bird, and Christopher P. Garrity

CC. Geology and Assessment of Undiscovered Oil and Gas Resources of the LomonosovMakarov Province, Central Arctic Ocean, 2008

By Thomas E. Moore, Kenneth J. Bird, and Janet K. Pitman

DD. Geology and Assessment of Undiscovered Oil and Gas Resources of the Eurasia Basin Province, Eastern Arctic Ocean, 2008

By Thomas E. Moore and Janet K. Pitman 


\section{Contents}

Abstract.

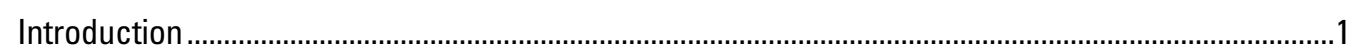

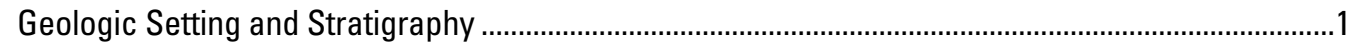

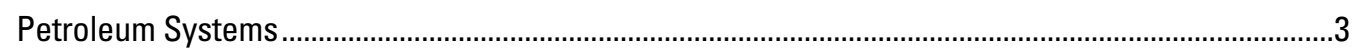

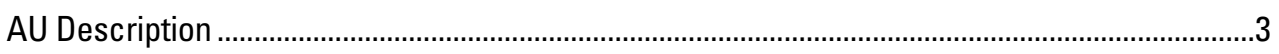

Geological Analysis of Assessment Unit Probability...............................................................

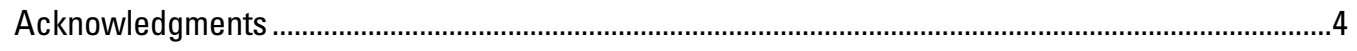

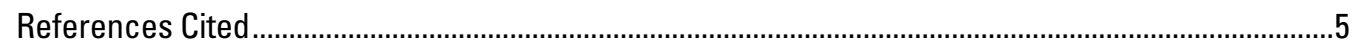

\section{Figures}

1. Map of Yukon Flats Basin in central Alaska .......................................................................

2. Schematic cross section of Yukon Flats Basin ....................................................................2

3. Example of one of several burial-history plots constructed by modeling a constant heat flow at a pseudowell located in the southern, deepest part of Yukon Flats Basin ................3 


\title{
Chapter F
}

\section{Geology and Assessment of Undiscovered Oil and Gas Resources of the Yukon Flats Basin Province, 2008}

\author{
By Kenneth J. Bird and Richard G. Stanley
}

\section{Abstract}

The hydrocarbon potential of the Yukon Flats Basin Province in Central Alaska was assessed in 2004 as part of an update to the National Oil and Gas Assessment. Three assessment units (AUs) were identified and assessed using a methodology somewhat different than that of the 2008 CircumArctic Resource Appraisal (CARA). An important difference in the methodology of the two assessments is that the 2004 assessment specified a minimum accumulation size of 0.5 million barrels of oil equivalent (MMBOE), whereas the 2008 CARA assessment specified a minimum size of $50 \mathrm{MMBOE}$. The 2004 assessment concluded that $>95$ percent of the estimated mean undiscovered oil and gas resources occur in a single AU, the Tertiary Sandstone AU. This is also the only AU of the three that extends north of the Arctic Circle.

For the CARA project, the number of oil and gas accumulations in the 2004 assessment of the Tertiary Sandstone AU was re-evaluated in terms of the $>50$-MMBOE minimum accumulation size. By this analysis, and assuming the resource to be evenly distributed across the AU, 0.23 oil fields and 1.20 gas fields larger than $50 \mathrm{MMBOE}$ are expected in the part of the AU north of the Arctic Circle. The geology suggests, however, that the area north of the Arctic Circle has a lower potential for oil and gas accumulations than the area to the south where the sedimentary section is thicker, larger volumes of hydrocarbons may have been generated, and potential structural traps are probably more abundant. Because of the low potential implied for the area of the AU north of the Arctic Circle, the Yukon Flats Tertiary Sandstone AU was not quantitatively assessed for the 2008 CARA.

\section{Introduction}

The Yukon Flats Basin is located south of the Brooks Range in east-central Alaska, covering an area of $\sim 36,000 \mathrm{~km}^{2}$ (fig. 1). About one-third of the basin $\left(\sim 12,000 \mathrm{~km}^{2}\right)$ lies north of the Arctic Circle. When assessed by the USGS in 2004 as part of an update to the National Oil and Gas Assessment (see http://energy. usgs.gov/OilGas/AssessmentsData/NationalOilGasAssessment.
aspx\#.Vykg8GQrKWZ), three hypothetical assessment units (AUs) were identified and assessed using a somewhat different methodology than that of the Circum-Arctic Resource Appraisal (CARA). An important difference is that the 2008 CARA included specification of a minimum accumulation size of 50 million barrels of oil equivalent (MMBOE), while the 2004 assessment used a smaller minimum accumulation size, 0.5 MMBOE (Stanley and others, 2004). In that (2004) assessment, $>95$ percent of the mean undiscovered oil and gas resources were estimated to occur in a single AU, the Tertiary Sandstone AU. Because most of the resources were estimated to occur in that $\mathrm{AU}$ - the only one in the province that extends north of the Arctic Circle - we reviewed the Tertiary Sandstone AU as part of the 2008 assessment, for which the minimum technically recoverable accumulation size was set at $50 \mathrm{MMBOE}$.

\section{Geologic Setting and Stratigraphy}

The broad Yukon Flats lowland is inferred from seismic reflection, gravity, and magnetic surveys (Saltus and others, 2007) to be underlain by a sedimentary basin filled with as much as $8 \mathrm{~km}$ of Upper Cretaceous(?) and Cenozoic nonmarine sedimentary and volcanic rocks (figs. 1, 2). No deep exploratory wells have been drilled in the Yukon Flats region, and the character of the basin fill is inferred from studies of shallow coreholes (Barker and others, 2005) and outcrops in the basin and surrounding region (Dover, 1994; Kirschner, 1994; Patton and others, 1994; Till and others, 2006, 2008; Troutman and Stanley, 2003). The basin appears to be filled by Late Cretaceous(?) and Tertiary sedimentary strata that include sandstone, mudstone, shale, and coal of fluvial and lacustrine origin, as well as volcanic rocks that range in composition from basalt to rhyolite (Rowan and Stanley, 2008). The origin of the basin is uncertain; it may be a product of latest Cretaceous(?) and early Tertiary extension and right-lateral movement along the Tintina Fault System (Till and others, 2005) or mid-Paleocene to early Eocene crustal extension related to subduction of an oceanic spreading center (Bradley and others, 2003). Seismic reflection profiles from south of the 


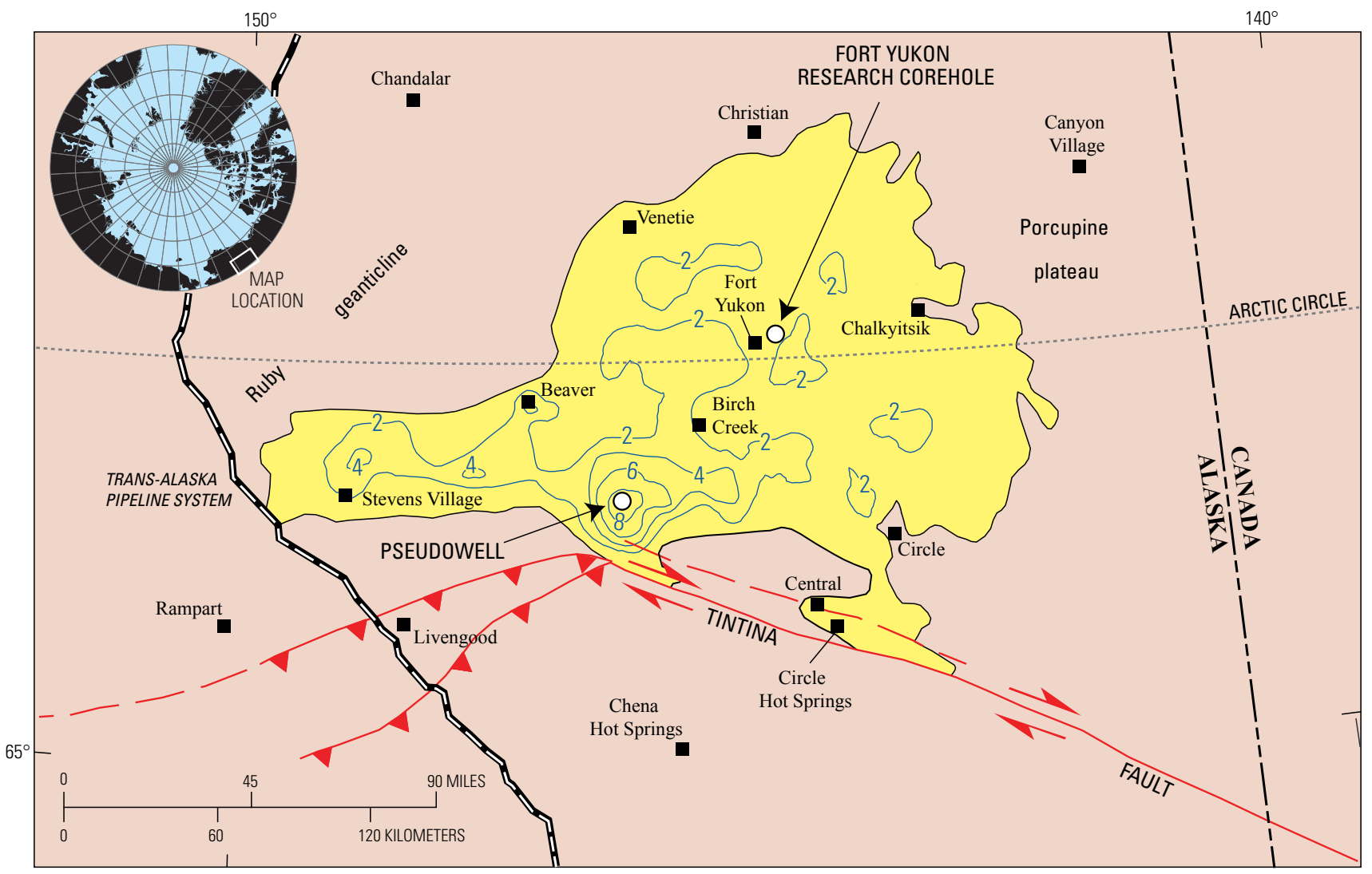

Figure 1. Map of Yukon Flats Basin (yellow area) in central Alaska showing interpreted depth to basement (blue contours), in thousands of meters, and location of 2,300-feet-deep (700 meters) Fort Yukon research well (fig. 2). Red lines are faults; sense of motion is indicated with arrows where known, and teeth are shown on overriding side of thrust faults. Adapted from Grantz and others (2010) and Rowan and Stanley (2008).

WEST

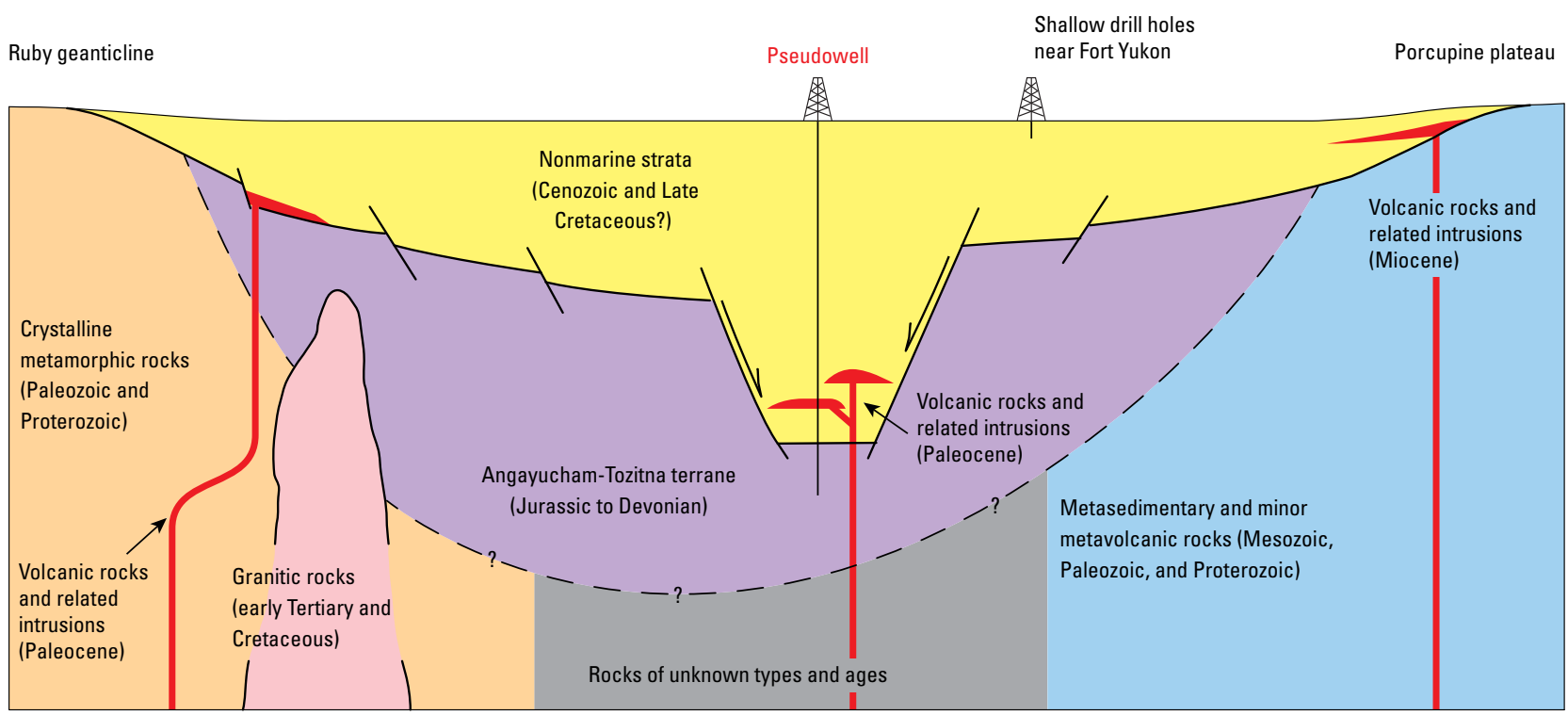

Figure 2. Schematic cross section of Yukon Flats Basin, as much as 200 miles (320 kilometers) wide and 25,000 feet (8,000 meters) deep, showing location of pseudowell used in burial history analysis. Adapted from Rowan and Stanley (2008). 
Arctic Circle show that the basin fill is folded and faulted near the Tintina Fault and that the intensity of deformation decreases northward with increasing distance from the fault. No seismicreflection profiles are available from north of the Arctic Circle in the Yukon Flats Basin.

\section{Petroleum Systems}

A single petroleum system, the Yukon Flats Tertiary composite total petroleum system, is hypothesized to exist in the Yukon Flats Basin (Stanley and others, 2004). Potential source rocks are postulated to be coal, shale, and lacustrine mudstone. The only hydrocarbons identified in the basin consist of an undetermined amount of gas encountered in
Miocene coal beds in the 2,300-ft-deep research corehole at Fort Yukon (fig. 1; Barker and others, 2005). Thermal maturity and the timing of petroleum generation have been modeled in the southern (deepest) part of the basin (Rowan and Stanley, 2008). Using a relatively high heat flow characteristic of young extensional basins, analysis of a pseudowell (fig. 3) suggests that the onset of petroleum generation could have occurred following $\sim 2 \mathrm{~km}(6,500$ feet $)$ of sedimentary burial and as early as $57 \mathrm{Ma}$. In the Yukon Flats Basin, most of the areas with inferred sedimentary deposits $>2 \mathrm{~km}$ thick occur south of the Arctic Circle.

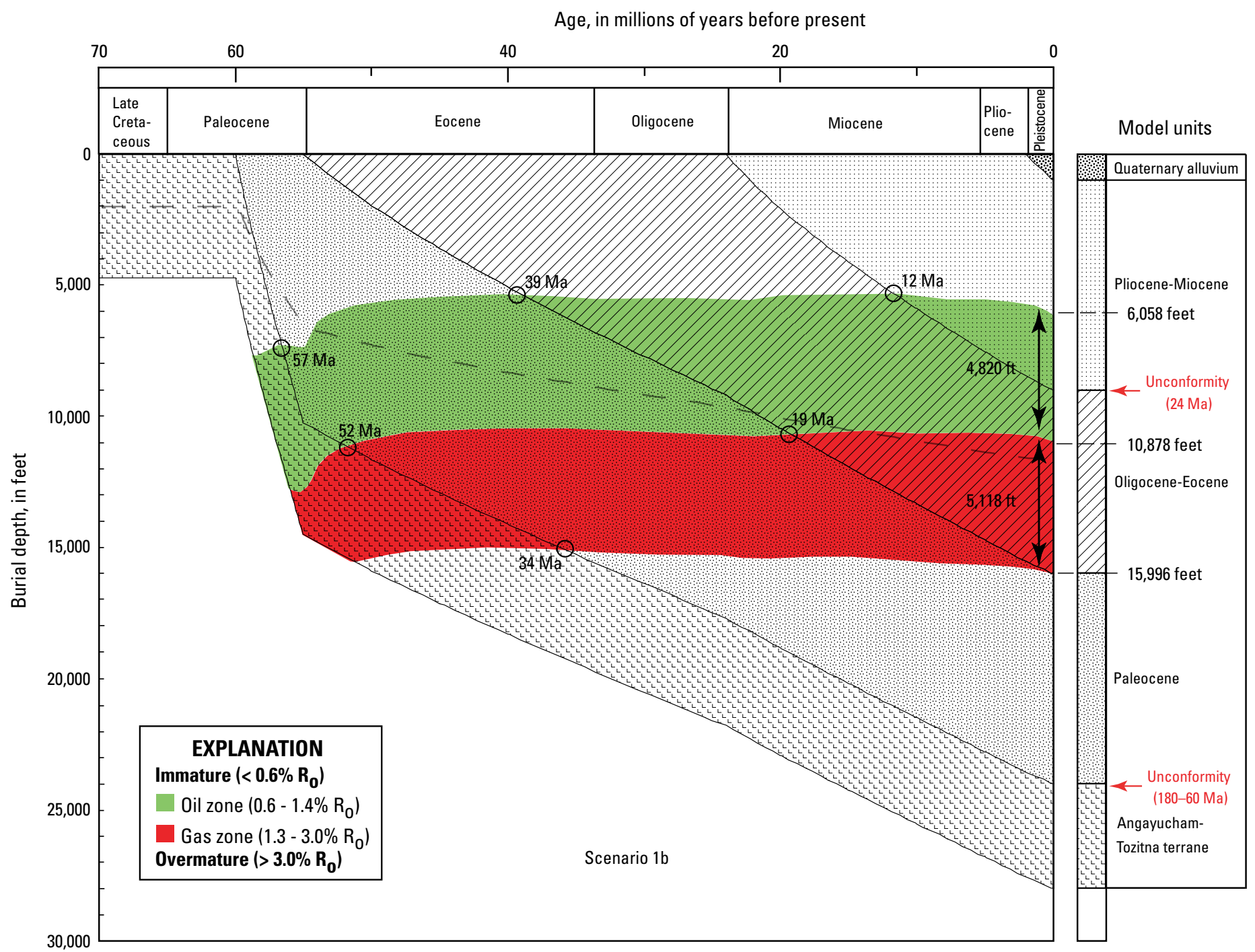

Figure 3. Example of scenario $1 \mathrm{~b}$ burial-history plot, one of several constructed by modeling a constant heat flow $(77$ milliwatts per square meter) at a pseudowell located in the southern, deepest part of Yukon Flats Basin (fig. 1). Ro, vitrinite reflectance, in percent (\%); Ma, millions of years ago. From Rowan and Stanley (2008). 


\section{AU Description}

The Tertiary Sandstone AU encompasses the entire Yukon Flats Basin, an area of $\sim 36,000 \mathrm{~km}^{2}$ (fig. 1). This AU is inferred to consist of as much as $8 \mathrm{~km}$ of Cenozoic nonmarine sandstone, conglomerate, volcanic rocks, shale, lacustrine mudstone, and coal. Petroleum source rocks are postulated to be coal, shale, and lacustrine mudstone. Burial-history modeling using a relatively high heat flow characteristic of young extensional basins indicates that the onset of petroleum generation could occur at depths of slightly less than $2 \mathrm{~km}$ (Rowan and Stanley, 2008).

\section{Geological Analysis of Assessment Unit Probability}

Data used for the 2004 National Oil and Gas Assessment of the Yukon Flats Tertiary Sandstone AU (Stanley and others, 2004) included size distributions for oil and gas fields that were based on a minimum size of $0.5 \mathrm{MMBOE}(0.5$ million barrels of oil [MMBO] or 3 billion cubic feet of gas [BCFG]). Using those field-size distributions, the estimated mean numbers of undiscovered oil and gas fields (13.67 oil fields and 67 gas fields, unrisked), and the probability of at least one undiscovered field in the $\mathrm{AU}(0.81)$, one can calculate mean estimates of undiscovered oil and gas fields of at least 50 MMBOE, the minimum for CARA: 0.67 oil fields and 3.52 gas fields.

The proportion of the Yukon Flats Tertiary Sandstone AU north of the Arctic Circle is 34 percent. Thus, if the resource is assumed to be evenly distributed across the $\mathrm{AU}$, then 0.23 oil fields and 1.20 gas fields larger that $50 \mathrm{MMBOE}$ are expected in the part of the AU north of the Arctic Circle. The geology suggests, however, that the area north of the Arctic Circle has lower potential than the area to the south where the sedimentary section is thicker, larger volumes of hydrocarbons may have been generated, and potential structural traps are probably more abundant. Because of the low potential implied for the area north of the Arctic Circle, the Yukon Flats Tertiary Sandstone AU was not quantitatively assessed for CARA.

\section{Acknowledgments}

We thank Bob Morin and Rick Saltus, whose reviews improved this manuscript.

\section{References Cited}

Barker, C.E., Clark, A.C., Clough, J.G., Maclean, E.A., Ogbe, D.O., Clautice, K.H., Weeks, E.P., and Fisk, R.F., 2005, Shallow coalbed gas assessment at Fort Yukon, Alaska [abs.]: Geological Society of America, Cordilleran Section Meeting, Abstracts with Programs, v. 37, no. 4, p. 95. [Also available at http:/gsa.confex.com/gsa/2005CD/finalprogram/ abstract_85773.htm.]

Bradley, D.C., Kusky, T.M., Haeussler, P.J., Goldfarb, R.J., Miller, M.L., Dumoulin, J.A., Nelson, S.W., and Karl, S.M., 2003, Geologic signature of early Tertiary ridge subduction in Alaska, in Sisson, V.B., Roeske, S.M., and Pavlis, T.L., eds., Geology of a transpressional orogen developed during ridgetrench interaction along the North Pacific margin: Geological Society of America Special Paper 371, p. 19-49.

Dover, J., 1994, Geology of part of east-central Alaska, in Plafker, G.E., and Berg, H.C., eds., The Geology of Alaska: Geological Society of America, DNAG, The geology of North America, v. G1, p. 153-204.

Grantz, A., Scott, R., Drachev, S.S., and Moore, T.E., 2010, Tectonostratigraphic accumulations of the Arctic Region $\left(65^{\circ}-90^{\circ} \mathrm{N}\right)$ that may be prospective for hydrocarbons: American Association of Petroleum Geologists GIS-UDRIL Open-File library, 68 p., 4 sheets, scale 1:4,000,000.

Kirschner, C.E., 1994, Interior basins, in Plafker, G.E., and Berg, H.C., eds., The Geology of Alaska: Geological Society of America, DNAG, The geology of North America, v. G1, p. 469-493.

Patton, W.W., Jr., Box, S.E., Moll-Stalcup, E.J., and Miller, T.P., 1994, Geology of west-central Alaska, in Plafker, G., and Berg, H.C., eds., The Geology of Alaska: Geological Society of America, DNAG, The geology of North America, v. G1, p. 241-269.

Rowan, E.L., and Stanley, R.G., 2008, The Yukon Flats Cretaceous (?)-Tertiary extensional basin, east-central Alaska: U.S. Geological Survey Scientific Investigations Report 2007-5281, 12 p., http://pubs.usgs.gov/sir/2007/5281/.

Saltus, R.W., Phillips, J.D., Stanley, R.G., Till, A., and Morin, R.L., 2007, Geophysical characterization of pre-Cenozoic basement for hydrocarbon assessment, Yukon Flats, Alaska: U.S. Geological Survey Open-File Report 2007-1208. 
Stanley, R.G., and 15 others, 2004, Oil and gas assessment of Yukon Flats, east-central Alaska, 2004: U.S. Geological Survey Fact Sheet 2004-3121, 2 p., http://pubs.usgs.gov/fs/2004/3121/ fs2004-3121.pdf.

Till, A.B., Dumoulin, J.A., Harris, A.G., Moore, T.E., Bleick, H.A., and Siwiec, B., 2008, Bedrock geologic map of the southern Brooks Range, Alaska, and accompanying conodont data: U.S. Geological Survey Open-File Report 2008-1149, 57 p., 2 sheets, scale 1:500:000. [Also available at http://pubs. usgs.gov/of/2008/1149/.]

Till, A.B., Dumoulin, J.A., Phillips, J.D., Stanley, R.G., and Crews, J.M., 2006, Generalized bedrock geologic map, Yukon Flats region, east-central Alaska: U.S. Geological Survey Open-File Report 2006-1304, 25 p., scale 1:500,000. [Also available at http://pubs.usgs.gov/of/2006/1304/.]
Till, A.B., Stanley, R.G., O’Sullivan, P.B., Saltus, R.W., and Crews, J.M., 2005, Tectonic events leading to establishment of Yukon Flats basin, Alaska [abs.]: Geological Society of America, Cordilleran Section Meeting, Abstracts with Programs, v. 37, no. 4, p. 94. [Also available at http://gsa. confex.com/gsa/2005CD/finalprogram/abstract_85040.htm.]

Troutman, S.M., and Stanley, R.G., 2004, Maps showing sedimentary basins, surface thermal maturity, and indications of petroleum in the Central Alaska Province: U.S. Geological Survey Miscellaneous Field Studies Map MF-2428, 19 p., scale 1:2,500,000. [Also available at http://pubs.usgs.gov/ $\mathrm{mf} / 2003 / 2428 /$. 


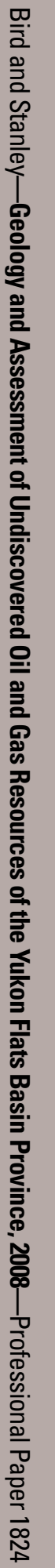

